\title{
COMMUnication In THE EARLY MODERN INDIAN OCEAN WORLD
}

\author{
Transforming Cultures eJournal, \\ Vol. 4 No 2 November 2009 \\ http://epress.lib.uts.edu.au/journals/TfC
}

\section{Michael Pearson ${ }^{1}$}

\begin{abstract}
People living on the shores of the early modern Indian Ocean spoke many languages. To communicate, whether for trade or other reasons, several strategies were found. I have already sketched the role of cultural brokers. The present study looks at silent trade, and the possibly existence of linguas franca, second languages widely spoken in the area. The two most commonly found were Portuguese and Arabic.

[Indian Ocean; lingua franca; silent trade]
\end{abstract}

Communication between people spread around such a diverse area as the early modern Indian Ocean littoral was hindered by the fact that people in different places spoke different languages. In any earlier piece I wrote about the role of cultural brokers, whose work made possible communication, and thus trade and cultural exchanges. ${ }^{2}$ I found that there were three ways in which cultural brokers facilitated communication between people with no language in common. These were the use of colleagues long settled in distant areas who could act as mediators for their itinerant fellows, the role of "sleeping dictionaries", and the work of professional cultural brokers.

There were other ways by which communication could be achieved. Three come to mind. They are, first and most obviously, when exchange occurs in a monolingual area. This requires no further discussion. The second is when exchange takes place without the use of a language. This is the "silent trade" phenomenon, where there was no verbal

\footnotetext{
1 Michael Pearson is Emeritus Professor at the University of New South Wales, Australia and Adjunct Professor at the University of Technology, Sydney. He has published widely on the Indian Ocean.

2 Michael Pearson "Cultural Brokers in the Indian Ocean", in Pamila Gupta, Isabel Hofmeyr \& Michael Pearson (eds.) Eyes Across the Water: Navigating the Indian Ocean, Johannesburg: University of South Africa Press \& New Delhi: Penguin India, in press.
} 
exchange, even though often the participants had a language in common The third example will detain us most. It is when there was a koine or lingua franca: that is, a widely known second language in a particular area. This greatly reduced the role of the cultural broker, or even rendered it redundant.

The famous phenomenon of "silent trade" was one way to make exchanges without using language at all. Curtin claims this has been greatly overrated, yet clearly it was widely used in India. ${ }^{3}$ We will first provide three extended contemporary accounts of how it worked. Pyrard wrote the classic account of it in Goa.

All the Indians at Goa and elsewhere have a custom, strange and notable enough, viz, when they would make some bargain one with another, and there be some folks present whom they would not hear the bargain and the price, nor should even have a suspicion of it, as might happen if they were to see them whispering together, they are wont to make signs under their silk or cotton mantles, which are worn like our cloaks; so touching the hands thus privily, they give one another to understand by the fingers at what price they are willing to buy or sell, without the others knowing or being aware of anything. 4

In the 1640s the jeweler Tavernier was at a diamond mine in Bijapur. Like Pyrard, he presents silent trade as an India-wide practice.

I have to record a rather singular and curious account of the manner in which the Indians, whether they are idolators or Musalmans, make their sales of all kinds of commodities. All passes in complete silence and without any one speaking. The seller and the buyer sit facing one another, like two tailors, and one of the two opening his waistband, the seller takes the right hand of the buyer and covers his own with his waistband, under which in the presence of many other merchants, who occupy themselves sometimes in the same manner, the sale is completed secretly without any one having cognizance of it. For the seller and the buyer talk neither by means of their lips nor their eyes, but only by the hand, which they manage to do in the following manner: when the seller takes the whole hand of the buyer that means 1,000, and as many times as he presses it so many thousand pagodas or rupees, according to the coin which may be in question. When he takes only five fingers this means 500, and when he takes only one it means 100 . By taking only the half up to the middle joint,

\footnotetext{
3 Philip Curtin (1984) Cross-Cultural Trade in World History, Cambridge: Cambridge University Press: 12-13.

4 François Pyrard (1887-90) The Voyage of François Pyrard of Laval to the East Indies, the Maldives, the Moluccas, and Brazil (trans.) A. Gray, London: Hakluyt, 2 vols, II: 179-80 and an informative footnote from Gray.
} 
50 is meant, and the end of the finger up to the first signifies 10. This is the whole mystery employed by the Indians in their sales, and it often happens that, in a place where there are many people, a single parcel will change hands five or six times without those present knowing for how much it has been sold on each occasion. 5

Carletti also left us a detailed account as part of his paeon of praise to the probity of Gujarati merchants.

Finally, they are renowned for extreme moral virtue in everything that they do, so that it would take a long time to tell about it. I shall only tell of the strange way in which their merchants behave when buying and selling goods. They do not speak aloud. But a middleman, who must work out the price of the things desired, takes one hand of the selling merchant and covers it up with his garment (they wear it long, of white cotton cloth, almost in the Turkish style), and without saying a word or giving any other sign, he presses the fingers of this hand, and this in a way to refer to hundreds or thousands, it being agreed that each finger means one hundred or one thousand, and similarly, by the same arrangement, tens, or even units. So that if the merchant wants to ask for 155 ducats for his goods from this middleman, he squeezes first a single finger of the hand, and by that action will say 'hundred.' Then he will take all the five fingers and, pressing them all at once, will say 'five tens.' Then, giving another squeeze to the five fingers, he will wish to say 'five,' and thus will have asked 155 ducats for his stuff without having spoken to the middleman. And then this latter, turning toward the buyer, takes his hand, and in the same manner and form tells him how much the seller is asking for his merchandise. If the buyer then wishes him to make an offer of 130 ducats, he takes one finger of the middleman's hand and, squeezing it, means: 'I will give one hundred ducats,' and then he squeezes three others together, and thus says 'and three tens more,' the sum of which makes up the 130. And thus - now with the buyer and now with the seller doing as I have described - the deal is consummated without a word being spoken aloud. Then what has been agreed to by this dumb show is spoken aloud. And what the middleman says is inviolably observed. And he, if not in accord with the sale, is not required to say anything about either the asking price or the offer made for the merchandise, so that under such circumstances nothing at all is known, and thus the negotiations are disclosed only to the three of them - seller, middleman, and buyer - and in that manner the goods keeps its reputation better and is easier to sell to another merchant. 6

\footnotetext{
5 Jean-Baptiste Tavernier (1977) Travels in India, (trans.) V. Ball \& (ed.) W. Crooke, 2 vols, New Delhi, II: 53-4, with more references in W. Crooke's footnote, where inter alia he says that this method is still widely found in India in livestock sales.

6 Francesco Carletti (1965) My Voyage Around the World, (trans.) Herbert Weinstock, London: 205-6.
} 
It is notable here that there is an intermediary involved, unlike in the first two instances we have quoted. It is also to be noted that this account makes clear that if a price is agreed, then it is announced publicly by the middleman.

There is evidence of this practice continuing well into the last century. William Crooke wrote that it was widespread in livestock sales in Northern India in the 1920s, and Alan Villiers noted it in the pearl fisheries of the Gulf in the late 1930s.

The sheik practiced a most curious method in his bargaining. When we approached a little pearler, or a big one, we would go aboard with quiet and unhurried dignity, be received with coffee and sweet confections, and discuss all manner of things for an hour or so before the subject of pearls was mentioned. Then in due course, out would come a piece of red flannel or an old black sock, and the nakhoda would carefully untie the bundle to display his take. They were always a lovely sight, and the sheik's eyes used to gleam, though he would invariably begin by decrying the gems and lamenting that the waters of the Gulf no longer produced pearls worth a buyer's attention. Then, in another hour or so, he would condescend to examine the take properly, sieving it and weighing the various grades, and examining some through a small magnifying glass. Only after several hours would the subject of a price be mentioned. Then would follow the usual sparring, always cheerful and conducted according to rule.

If he really intended to buy the pearls, the sheik would at last grab a spare piece of his red flannel, throw it over his right hand, grasp the right hand of the nakhoda beneath this flannel, and conduct the final negotiations by manipulation of fingers, according to some ancient code, in solemn and complete silence. Sometimes he varied the procedure by grabbing his brother's hand in the same manner, and working on his fingers, but this was when he wanted to get his brother's idea of the value of the parcel he was considering. 7

These long quotations require some commentary. First, it is important to distinguish this from the dumb barter or depot trade much analysed by anthropologists. That method of exchange does not involve any direct contact between two groups of traders. One group will leave trade goods at a designated spot and then retire. The other group will then approach and leave their goods. If the first group is satisfied, they take the second set of goods and leave. Then the second group of traders come back and take the goods left by the first group.

\footnotetext{
${ }^{7}$ Alan Villiers (1952) Monsoon Seas, New York: 238-9.
} 
Second, silent trade obviously is very limited. It makes possible only numeric exchanges: that is, bargaining over a price. While this could work in an economic exchange transaction, it obviously would be of no use in most situations where communication is needed. One could perhaps see the various grips and taps involved as themselves making a lingua franca, though it is unclear how universally known these gestures were, and the accounts above show some variations. The end of Tavernier's account also seems to point to the possibility of sharp practice.

The European accounts all seem to find this method unusual and exotic, so we must assume that it was not part of European practice, and nor did Europeans engage in it in India. However, the Villiers account suggests that its use was not restricted to India. As yet, however, I cannot say anything about its use or neglect in, say, Southeast Asia or east Asia.

Finally, it is clear that silent trade was not usually needed to overcome language differences, for our accounts make it clear that often the two parties involved spoke the same language. The objective in most cases was to keep transactions secret.

The more intriguing matter to raise is whether or not there was a second language, a koine or lingua franca, widely in use around the shores of the ocean. If there was, then communication would be much enhanced. Equally important, the existence of a widely used koine would reinforce claims that there was indeed an Indian Ocean World, with the littoral tied together not only by trade, and Islam, but also by a commonly understood second language.

First, some definitions. The Oxford English Dictionary defines koine as "Originally the common literary dialect of the Greeks . . . Now extended to include any language or dialect in regular use over a wide area in which different languages or dialects are, or were, in use locally." Lingua franca is defined similarly, as an auxiliary or compromise language used between groups having no other language in common. I will use the two terms interchangeably.

Especially for this linguistically challenged historian, there are a host of mine fields to be negotiated. Most important, I will be writing about the competing claims of Portuguese and Arabic as linguas franca, but both of these rubrics are far too 
unanalytical. To use them as fixed and unqualified is to assume that both were invariable and standardised in the early modern world, and this is far from the case. Quranic Arabic may have been known in madrasas, and by travelling scholars like Ibn Battuta, but one must assume that less sophisticated variants were also widely used. As an example, the language of the Swahili coast (and there are important differences in this language as one proceeds up and down the coast) drew on Bantu roots with an admixture of Arabic as conversions proceeded. It is to be remembered that most Arabic influences on Swahili came only in the nineteenth century. It is notable that Ibn Battua himself complained of the crude and rustic Arabic language he had to put up with as he travelled around the coasts of the Indian Ocean. The point is that he encountered many "Arabics".

So also with European languages. Spain and Italy at this time were home to a host of languages, rather than dialects, and even today regional variations are common. In the early modern period there was a Mediterranean patois, a medley including words from all the Romance areas, and also words from Greek and Arabic. Just as today in north India a speaker of standard Hindi can communicate to an extent with a speaker of any other Indo-European language, so also in our period people could understand, roughly, people whose native language was quite different, such as for example a Portuguese and a Milanese speaker. We have some information about creole Portuguese, but much less about the variants of standard Arabic used in the Indian Ocean area.

Qaisar, in his seminal study of brokers, claims that in the seventeenth century there seems to have developed "some kind of commercial language along the western coast". This consisted of a mixture of various languages, mostly Portuguese, and so was called "Negro Portuguese" by the English. However, rather unsatisfactorily he says that "it failed to continue for long". 8 This claim seems dubious, for we have many other examples of the role of Portuguese as a maritime lingua franca. It is well known that the Portuguese "stayed on" in Asia, unlike the Dutch and English, who usually went back to Europe. The consequence was that their language became very widely used by other Europeans, and some Asians, even long after Portuguese political power had declined. João de Barros famously wrote that

\footnotetext{
8 A. Jan Qaisar (1974) "The Role of Brokers in Medieval India," The Indian Historical Review, 1 (2): $230-31$.
} 
The Portuguese arms and pillars placed in Africa and in Asia, and in countless isles beyond the bounds of three continents, are material things, and time may destroy them. But time will not destroy the religion, customs, and language which the Portuguese have implanted in those lands. ${ }^{9}$

When the Dutch conquered Sri Lanka they were forced to use Portuguese to communicate with their new subjects. The king of Kandy, although an ally of the Dutch against the Portuguese, refused to receive letters from the Hollanders in Dutch: he insisted they be in Portuguese, which language he spoke and wrote fluently, as did the ruler of Makassar. Even in the VOC capital of Batavia it was a means of communication between Dutch men and their mestiça women. At the battle of Plassey in 1757, Clive used Portuguese to communicate with his troops. When Captain Hamilton was in Johore, a Muslim merchant had a problem with the king. An official came on board Hamilton's ship to try and settle things and Hamilton provided an interpreter for Portuguese. Apparently Portuguese was the lingua franca which connected a Malay speaker, an Arabic speaker, and the English speaking Hamilton. In Cambodia also Hamilton found Portuguese widely used, and indeed the king sent him a letter in Portuguese. 10

So also at the Cape, where in 1765 Mrs. Kindersley wrote vigorously that the slaves of the Dutch were

brought originally from different parts of the East Indies. What seems extraordinary is, that they do not learn to talk Dutch, but the Dutch people learn their dialect, which is called Portuguese; and is a corruption of that language, some of them are called Malays or Malaynese, brought from that country of Malacca, and the islands to the eastward of India, subject to the Dutch company. 11

She found the same in India. She wrote of Indian Christians, whom she considered to be very low people.

Their language is called Pariar Portuguese [linguists would probably describe this creole as "português baixo"] a vile mixture of almost every European language with some of the Indian. This is however a useful dialect

\footnotetext{
9 Quoted in C. R. Boxer (1961) Four Centuries of Portuguese Expansion, 1415-1825, Johannesburg: 93.

10 Alexander Hamilton (1930) A New Account of the East Indies, 2 vols, London: Argonaut, II: 51, $107-$ 8,83 respectively.

11 Mrs. Jemima Kindersley (1777) Letters from the Island of Teneriffe, Brazil, The Cape of Good Hope, and the East Indies, London: J. Nourse: 66-7, 169; P.E. Pieris (1929, 1973) The Dutch Power in Ceylon, 1602-1670, London: Curzon: 133.
} 
to travellers in many parts of Hindostan, particularly on the sea coast, and is called the lingua Franca of India. 12

As Mrs. Kindersley noted, the Portuguese spoken at the Cape was "corrupted". A less judgemental phrasing would say it was a creole language. Creole languages typically have a dominant linguistic base, which is added to and often simplified. Well known examples are Louisiana Creole (derived from French), and Melanesian Pidgin (derived from English). Sousa Rebelo notes that the various Portugueses spoken around the littoral were grammatically simplified languages, or creoles. There were several of them, as in Malacca, Sri Lanka, and Macau. ${ }^{13}$ The very experienced Captain Hamilton, in 1727, found that almost no Asians knew English, but plenty spoke Portuguese.
Along the sea coasts, the Portuguese have left a vestige of their language, tho' much corrupted, yet it is the language that most Europeans learn first, to qualify them for a general converse with one another, as well as with the different inhabitants of India. 14

Furber noted that creole Portuguese was the lingua franca of commerce from the Red Sea to Canton. The EIC had 200 Portuguese dictionaries in its Indian settlements in 1709, and Portuguese was widely used as the medium of instruction in schools in European factories. 15

An important caveat is in order. It seems clear that many scholars have made claims for Portuguese which are derived from European sources, and which are essentially Eurocentric. The real situation seems to be that Europeans often found Portuguese useful as a medium of communication, both with other Europeans and with some Asian port city residents. However to go from this to promote Portuguese as the littoral lingua franca is invalid. Most traders in the Indian Ocean region in the early modern period were not Europeans: most of them were Muslims from a wide variety of places. A Portuguese creole may have been the lingua franca of the Cape and India, but only for Europeans, or when one party to an exchange was European.

\footnotetext{
12 Kindersley (1777: 169).

13 Souza Rebelo (2007) "Language and Literature in the Portuguese Empire", in Francisco Bethencourt \& Diogo Ramada Curto (eds.) Portuguese Oceanic Expansion, 1400-1800, New York: Cambridge University Press: 372-5.

14 Hamilton (1930: I, 7-8).

15 Holden Furber (1976) Rival Empires of Trade in the Orient, 1600-1800, Minneapolis: 298-99.
} 
Thus it is extremely unlikely that, say, a Persian, a Malay and a Gujarati in Surat would converse in Portuguese. This leads us to a discussion of the role of the alternative koine, namely Arabic In many coastal areas, though perhaps more in East Africa and Indonesia, knowledge of Arabic gave access to a higher culture: that is, Islamic scriptural data and traditions. This was why Ibn Battuta could travel all around the littoral and apparently use only Arabic to communicate. Considering himself to be an exemplar of the Faith in these remote and sometimes barbarous regions, he contemptuously refused to use any language other than that of the Prophet. Even the Portuguese found that those of them who had picked up some Arabic in Morocco were extremely valuable in fostering communication in many areas of the littoral. Eleana Losada Soler makes the bold and intriguing claim that the Portuguese found Arabic acting as a koine. ${ }^{16}$ The point here is that it is apparent that while some locals in the Indian Ocean spoke one or more Romance languages, this was obviously of little use when Indian Ocean native traders wanted to communicate across linguistic boundaries, such as a Malay-speaking person with one from Gujarat. Yet such communication was much more widespread and important that any interaction with a Portuguese or other European, and it seems very likely that the common language then was indeed a version of Arabic. Serjeant noted more generally that Arab traders from particular places had their own brokers in ports where they called, though on the Somali coast they could use any dallal or broker. In either case Arabic was the language used on both sides. ${ }^{17}$

Nor is this a matter for surprise, since of course most of the littoral population, and the traders, were Muslim of one sort or another, so one could expect that they would have at least a smattering of Arabic anyway, regardless of commerce, just because this was the liturgical language with which they would have at least some familiarity. Anne Bang's seminal work on Muslim scholars and travellers in the nineteenth century holds good for our period also. Scholars and ulama perforce needed Arabic to access the enormous scriptural Arabic tradition, on which Islamic law and theology rested. This was

\footnotetext{
16 Elena Losada Soler (2000) "The Encounter of Languages: Reflections on the Language of the Other in Roteiro da Primeira Viagem do Vasco da Gama", in Anthony Disney \& Emily Booth (eds.) Vasco da Gama and the Linking of Europe and Asia, New Delhi: Oxford University Press: 204.

17 R.B. Serjeant (1970) "Maritime Customary Law off the Arabian coasts" in M. Mollat (ed.) Societés et companies, Paris: SEVPEN: 203-4.
} 
reinforced by travel for hajj or study to the Hijaz, where correct Arabic was instilled. 18 It is important to remember that not only Ibn Battuta was able to use his Arabic all around the littoral. Everywhere he went he found religious dignitaries from the Middle East holding prestigious positions in Indian Ocean port cities - these men would, of course, be outside the knowledge of visiting Europeans. However, the Portuguese did complain frequently about travelling cacizes (religious guides) converting local people all around the shores of the ocean and far into Southeast Asia: their language also was Arabic. Finally, there were many navigational treatises circulating in the area, the most famous being the late fifteenth century one by Ibn Majid. One must not make too much of this, as many Muslim seamen were illiterate, and many more relied on traditional navigational techniques, summed up as wayfinding, rather than on books.

The final question is the matter of the creolisation of Arabic. On the face of it, one may think that Arabic, being a liturgical language, and the one chosen by Allah to reveal his final message, was less susceptible to creolisation and borrowing than were other languages. Yet this is really a very extreme statement, for it beggars belief to assume that every humble Muslim trader spoke classical Arabic. Yet again, the way Ibn Battuta ridiculed the faulty Arabic of many of his interlocutors, even commenting on their pronunciation, shows that creole Arabic, or perhaps the versions of Arabic used by common folk around the ocean, was far from the pure language of the Quran. It is notable that the Portuguese soon found that their Moroccan Arabic was rather different from other versions found in the Indian Ocean region. One final hint is given by the experience of the English Captain Keeling. In the early seventeenth century he spent three months in Socotra and learnt a smattering of Arabic, which came in handy later in the Comoros: "Heere my Arabeck did us much pleasure". 19 Even his "smattering" meant he could communicate. In sum, there seems to be clear evidence that varieties of Arabic were widely known and used as a lingua franca in the early modern Indian Ocean region. Portuguese played a more specialized role, being used primarily when one party to an exchange was European.

\footnotetext{
18 See especially Anne Bang (2003) Sufis and Scholars of the Sea: family networks in East Africa, 18601925, London: Routledge.

19 Michael Strachan \& Boies Penrose (eds.) (1971) The East India Journals of Captain William Keeling and Master Thomas Bonner, 1615-1617, Minneapolis: University of Minnesota Press: 25, 92.
} 


\section{Bibliography}

Bang, Anne (2003) Sufis and Scholars of the Sea: family networks in East Africa, 18601925, London: Routledge.

Boxer, C. R. (1961) Four Centuries of Portuguese Expansion, 1415-1825, Johannesburg: Witwatersrand University Press.

Carletti, Francesco (1965) My Voyage Around the World, (trans.) Herbert Weinstock, London: Pantheon Books.

Curtin, Philip (1984) Cross-Cultural Trade in World History, Cambridge: Cambridge University Press.

Furber, Holden (1976) Rival Empires of Trade in the Orient, 1600-1800, Minneapolis: University of Minnesota Press.

Hamilton, Alexander (1930) A New Account of the East Indies, 2 vols, London: Argonaut.

Kindersley, Mrs. Jemima (1777) Letters from the Island of Teneriffe, Brazil, The Cape of Good Hope, and the East Indies, London: J. Nourse.

Michael Pearson (in press) "Cultural Brokers in the Indian Ocean”, in Pamila Gupta, Isabel Hofmeyr \& Michael Pearson (eds.) Eyes Across the Water: Navigating the Indian Ocean, Johannesburg: University of South Africa Press and Delhi: Penguin India.

Pieris, P. E. (1929, 1973) The Dutch Power in Ceylon, 1602-1670, London: Curzon.

Pyrard, François (1887-90) The Voyage of François Pyrard of Laval to the East Indies, the Maldives, the Moluccas, and Brazil, (trans.) A. Gray, 2 vols, London: Hakluyt.

Qaisar, Jan A. (1974) "The Role of Brokers in Medieval India," The Indian Historical Review, 1 (2): 230-31.

Rebelo, Souza (2007) "Language and Literature in the Portuguese Empire" in Francisco Bethencourt \& Diogo Ramada Curto (eds.) Portuguese Oceanic Expansion, 1400-1800, New York: Cambrdige U.P.

Serjeant, R. B. (1970) "Maritime Customary Law off the Arabian coasts" in M. Mollat (ed.) Societés et companies, Paris: SEVPEN.

Soler, Elena Losada (2000) "The Encounter of Languages: Reflections on the Language of the Other in Roteiro da Primeira Viagem do Vasco da Gama", in Anthony Disney \& Emily Booth (eds.) Vasco da Gama and the Linking of Europe and Asia, New Delhi: Oxford U.P.

Strachan, Michael \& Penrose, Boies (eds.) (1971) The East India Journals of Captain William Keeling and Master Thomas Bonner, 1615-1617, Minneapolis: University of Minnesota Press.

Tavernier, Jean-Baptiste (1977) Travels in India, (trans.) V. Ball \& (ed.) W. Crooke, 2 vols, New Delhi: Oriental Books Reprint Corporation.

Villiers, Alan (1952) Monsoon Seas, New York: McGraw-Hill Book Co. 